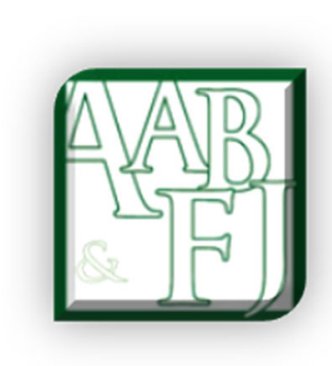

\title{
Editorial Volume 14 Issue 2
}

\author{
Ciorstan Smark ${ }^{1}$ and Monir Mir ${ }^{2}$
}

AABFJ hopes that all of our readers and authors are safe and well during these difficult times. We pay tribute to those health and emergency workers who are on the front line of the international Covid 19 health crisis. We also think of the many students and academics who have had to face many challenges during this time of distance study and social distance.

This issue of AABFJ brings together a wide variety of articles from Australia and Asia. From finance, Leow and Lau (2020) examines the impact of the heuristic representation on flipping activity in an emerging market, Malaysia. Leow and Lau (2020) had four main findings. That the distribution of initial return, oversubscription ratio, firm age, offer period, firm size, heuristic representation, and flipping activity are positively skewed. That the oversubscription ratio has a positive relationship with flipping activity. That heuristic representation influences the relationship between oversubscription ratio and flipping activity. They concluded that it was untrue that Malaysian investors were active in subsequent trading but not necessarily obtaining a profit from liquidation.

Also, from finance, Harymawan, Nasih, Agustia, Ratri and Nowland (2020) examined how research and development investment in Indonesia was related to the educational backgraound of the firms' CEO and CFO.

De Silva Lokuwaduge and de Silva (2020) present an article on corporate disclosure of environmental, social and governance risks. This article looks particularly at Australian companies in the extractive sectors' disclosures. Again in the area of ecological accounting, Bhattacharyya, Biswas and Moyeen (2020) compare the aspiring managers from India and Australia and consider whether their personal values may influence their subsequent environmental choices.

From the area of privatization in Australia, Jayasundara, Jones and Sands (2020) look at the contradiction between the Theory of the Firm and Stakeholder Theory in a case study reflecting on privatization in the Port of Brisbane.

\footnotetext{
${ }^{1}$ University of Wollongong, Australia

${ }^{2}$ University of Canberra, Australia
} 


\section{References}

Bhattacharyya, Asit; Biswas, Kumar; and Moyeen, Abdul, Determinants of Pro-environmental Behaviours - A Cross Country Study of Would-be Managers, Australasian Accounting, Business and Finance Journal, 14(2), 2020, 51-71. doi:10.14453/aabfj.v14i2.5

de Silva Lokuwaduge, Chitra S. and de Silva, Keshara, (2020), Emerging Corporate Disclosure of Environmental Social and Governance (ESG) Risks: An Australian Study, Australasian Accounting, Business and Finance Journal, 14(2), 2020, 35-50. doi:10.14453/aabfj.v14i2.4

Harymawan, Iman; Nasih, Mohammad; Agustia, Dian; Ratri, Melinda Cahyaning; and Nowland, John, (2020), CEO \& CFO Education and R\&D Investment in Indonesia, Australasian Accounting, Business and Finance Journal, 14(2), 2020, 1634. doi:10.14453/aabfj.v14i2.3

Jayasundara, Mudiyanselage Upali Ranjith; Jones, Greg; and Sands, John, (2020), Financial and Social Well-being Performance after Privatisation of the Portof- Brisbane: A Case Study, Australasian Accounting, Business and Finance Journal, 14(2), 2020, 72-93. doi:10.14453/aabfj.v14i2.6

Leow, Hon-Wei and Lau, Wee-Yeap, (2020), The Interaction Effect of Heuristic Representation on Initial Public Offering Anomaly: Evidence from Flipping Activity, Australasian Accounting, Business and Finance Journal, 14(2), 2020, 3-15. doi:10.14453/aabfj.v14i2.2 